\title{
Pensononowoor
}

2015, vol. 73, 163-173

http://dx.doi.org/10.12657/denbio.073.017

\author{
Srđan Stojnić, Saša Orlović, Branislav Trudić, Uroš Živković, \\ Georg von Wuehlisch, Danijela Miljković
}

\section{Phenotypic plasticity of European beech (Fagus sylvatica L.) stomatal features under water deficit assessed in provenance trial}

Received: 8 April 2014; Accepted: 25 September 2014

\begin{abstract}
The results of research into leaf stomatal variability of five European beech provenances originating from Austria, Bosnia and Hercegovina, Germany, Romania and Serbia are presented in this paper. Aim of the study was to investigate how stomatal traits of provenances originating from different environments change in response to drought stress and to assess the phenotypic plasticity of the stomatal features investigated. The study was conducted during two different years, characterized by contrasting weather conditions (2010 and 2011). Two-way ANOVA revealed that provenances differ significantly in terms of stomatal density $(\mathrm{SD})$, width of stomatal aperture $\left(\mathrm{W}_{\mathrm{b}}\right)$, potential conductance index $(\mathrm{PCI})$ and relative stomatal pore surface (RSPS), during both seasons. In a dry year (2011) all provenances significantly increased stomatal density by between $16.1 \%$ (Hasbruch - DE) and $21.9 \%$ (Cer - SRB). Guard cell length $\left(\mathrm{L}_{\mathrm{A}}\right)$ was not statistically different among provenances in either year (2010 and 2011), even though $\mathrm{L}_{\mathrm{A}}$ decreased in the dry year (2011) in all provenances. Reaction norms were steep in most of the parameters suggesting the possibility of a plastic response of provenances toward changes in soil water regime, influenced by the prevailing weather each year. Phenotypic plasticity indices were the highest in regards of SD, PCI and RSPS, indicating that these traits would be good candidates for improvement in breeding programs aimed at selection of drought resistant.
\end{abstract}

Additional key words: European beech, provenance trial, reaction norms, phenotypic plasticity

Addresses: S. Stojnić, S. Orlović, B. Trudić, University of Novi Sad, Institute of Lowland Forestry and Environment, Antona Čehova 13, 21000 Novi Sad, Republic of Serbia, e-mail: stojnics@uns.ac.rs U. Živković, D. Miljković, University of Belgrade, Institute for Biological Research Siniša Stanković, Department of Evolutionary Biology, Bulevar Despota Stefana 132, 11000 Belgrade, Republic of Serbia G. von Wuehlisch, Johann-Heinrich von Thünen-Institute, Institute for Forest Genetics, Sieker Landstr. 2, D-22927 Großhansdorf, Germany

\section{Introduction}

Stomata hold a key role in adaptation of plants to changes in their environment. They allow gas exchange through the opening and closing of the stomatal pore, regulating photosynthesis and water movement inside plants. Another strategy of plants to adjust to environmental conditions is the possibility of modulating stomatal size and density development during leaf formation (Hamanishi et al. 
2012). In this way, plants are able to control their water balance and optimize photosynthetic performance to the available water supply (Casson and Gray 2008).

Affecting plant productivity and growth, drought stress is probably one of the most important abiotic disturbances in temperate bioclimatic zone (Lindner et al. 2010). Water deficit may reduce leaf gas exchange by both stomatal and non-stomatal limitations (Xu and Zhou 2008). Stomatal limitation occurs largely during mild to moderate drought stress (Flexas and Medrano 2002), resulting in closing of stomata in order to prevent water loss through transpiration. For example, Gallé and Feller (2007) found that successive limitation in water availability led to the parallel decreasing in net photosynthesis and stomatal conductance, pointing at the regulative function of stomata in minimizing water loss under limited water supply. In addition, non-stomatal or biochemical limitation is quantitatively important during leaf ageing and severe drought (Grassi and Magnani 2005). This limitation comprises diffusive resistances within the leaf and inhibition of metabolic processes (Flexas and Medrano 2002; Gallé and Feller 2007).

For drought tolerance, stomata have a vital place in breeding programs, even though sometimes it is difficult to find the optimal balance between characters that conserve water and those needed to maximize production (Jones 1987). Based on projections of global climate change and well-known vulnerability of European beech to water shortage, it seems that the predominant task for forest geneticists will be detection of those provenances that exhibit stomatal responsiveness to water stress and that are therefore likely to tolerate stress. From that point, investigation of phenotypic plasticity in stomata is of great importance, because plasticity is considered as one of the most important mechanisms allowing trees to cope with environmental heterogeneity (Sultan 2000).

This study compares the phenotypic variation in ten stomatal features (stomatal density, length and width of stomata guard cell, stomatal aperture length and width, stomatal pore surface of stomata guard cell, stomatal pore surface of a widely opened stomatal pore, stomatal shape coefficient, potential conductance index and relative stomatal pore surface), across five European beech provenances, during two successive growing seasons, contrasting by climate conditions (wet and dry). Until now, plastic response of beech to drought has already been documented for biomass partitioning (Löf et al. 2005), root traits (Meier and Leuschner 2008) and wood-anatomical structure (Stojnić et al. 2013).

Hypothesis of this study is based on the idea that stomatal traits react plastically to their environment, thereby adapting to environmental factors (Van Wittenberghe et al. 2012). Therefore, we considered that dry weather conditions and soil water deficit during the second growing season (2011) will increase stomatal density in European beech provenances, as well as reduce stomatal size, comparing to the first one (2010). As an extension to the previous hypothesis, the objective of this study was to answer the question how different European beech provenances respond to distinct climate conditions in terms of leaf stomatal features.

\section{Material and methods}

\section{Site description, plant material and microclimate}

The study involves five European beech provenances of different origin, growing at the provenance trial (Table 1), located on the Fruska Gora Mountain, in the Northern part of Serbia. The trial was established in spring 2007, by planting 3-year-old saplings. Geographical coordinates of the plot are: N $45^{\circ} 10^{\prime} 9.86^{\prime \prime}, \mathrm{E} 19^{\circ} 47^{\prime} 53.45^{\prime \prime}$. The study was conducted on the saplings at the age of 6 (2010) and the age of 7 (2011).

The trial site has an altitude approximately 370 $\mathrm{m}$ a.s.l. and a northwestern exposition. Around the trial, a buffer zone of 2 rows was planted with the local provenance. The soil is an acid brown soil $(\mathrm{pH}$ 5.4). The mountain climate is temperate continental: mean air temperature is $11.1^{\circ} \mathrm{C}$ and the yearly

Table 1. European beech provenances used in the study.

\begin{tabular}{|c|c|c|c|c|c|c|c|c|c|}
\hline \multirow{2}{*}{ Acronym } & \multirow{2}{*}{ Provenance } & \multicolumn{2}{|c|}{$\begin{array}{c}\text { Geographical } \\
\text { coordinates }\end{array}$} & \multirow{2}{*}{$\begin{array}{l}\text { Country of } \\
\text { origin }\end{array}$} & \multirow{2}{*}{$\begin{array}{l}\text { Altitude } \\
\text { (m) }\end{array}$} & \multirow{2}{*}{$\begin{array}{l}\text { Annual } \\
\text { mean air } \\
\text { temp. }\left({ }^{\circ} \mathrm{C}\right)\end{array}$} & \multirow{2}{*}{$\begin{array}{l}\text { Mean temp. } \\
\text { during } \\
\text { veg. per. }\left({ }^{\circ} \mathrm{C}\right)\end{array}$} & \multirow{2}{*}{$\begin{array}{c}\text { Annual } \\
\text { sum of } \\
\text { precip. (mm) }\end{array}$} & \multirow{2}{*}{$\begin{array}{l}\text { Sum of prec. } \\
\text { during } \\
\text { veg. per. }\left({ }^{\circ} \mathrm{C}\right)\end{array}$} \\
\hline & & $\begin{array}{l}\text { Latitude } \\
\text { (deg.min) }\end{array}$ & $\begin{array}{l}\text { Longitude } \\
\text { (deg. min.) }\end{array}$ & & & & & & \\
\hline BA32 & Crni Vrh, Tešanj & $44^{\circ} 33^{\prime}$ & $17^{\circ} 59^{\prime}$ & $\begin{array}{c}\text { Bosnia and } \\
\text { Herzegovina }\end{array}$ & 500 & 9.6 & 15.9 & 1069 & 579 \\
\hline DE49 & Hasbruch & $53^{\circ} 08^{\prime}$ & $08^{\circ} 26^{\prime}$ & Germany & 35 & 8.6 & 15.0 & 760 & 360 \\
\hline AT56 & $\begin{array}{l}\text { Scharnstein, } \\
\text { Mitterndorf }\end{array}$ & $47^{\circ} 54^{\prime}$ & $13^{\circ} 58^{\prime}$ & Austria & 480 & 7.4 & 14.6 & 1263 & 706 \\
\hline RO63 & Alesd & $47^{\circ} 11^{\prime}$ & $22^{\circ} 15^{\prime}$ & Romania & 490 & 8.5 & 18.3 & 800 & 397 \\
\hline RS69 & Cer & $44^{\circ} 12^{\prime}$ & $19^{\circ} 50^{\prime}$ & Serbia & 745 & 9.5 & 15.4 & 847 & 476 \\
\hline
\end{tabular}


precipitation is $624 \mathrm{~mm}$. Mean average temperature, during the vegetation period (April - September) amounts to $17.8^{\circ} \mathrm{C}$, and the average precipitation, in the same period, is $369 \mathrm{~mm}$ ( $45 \%$ of total annual precipitation). The climate records are from the weather station Rimski Sancevi (N 4520', E 19॰51'; $84 \mathrm{~m}$ a.s.l.), at a distance of $30 \mathrm{~km}$ from the trial. Environmental conditions in the European beech provenance trials in Serbia were described in detail by Stojnić et al. (2012).

\section{Weather conditions}

Data regarding monthly mean temperatures and monthly precipitation for certain years (RHMZ 2010; RHMZ 2011; RHMZ 2012) have been taken from the Meteorological station "Rimski Šančevi” (N 4520', E $19^{\circ} 51^{\prime} ; 84 \mathrm{~m}$ a.s.1.). For defining the dry season we adopted the definition of Bagnouls and Gaussen (1953) (Fig. 2). The Gaussen-Bagnouls xerotherm index was calculated on the basis of monthly rainfall and temperature (Mészáros et al. 2007). According to this index, a month is considered as dry when the rainfall (in $\mathrm{mm}$ ) is equal to or less than twice the value of its mean temperature (in $\left.{ }^{\circ} \mathrm{C}\right)\left(\mathrm{P} \leq 2^{*} \mathrm{~T}\right)$ (Bagnouls and Gaussen 1953).

Empirical equation for calculating the saturation vapor pressure $\left(e_{s}\right)$ from temperature is the Tetens formula (Buck 1981):

$$
e_{s}=a \exp \left(\frac{b T}{c+T}\right)
$$

where: $T$ is mean air temperature in ${ }^{\circ} \mathrm{C}$, the constants $a, b$, and $c$ can be chosen to optimize the fit of the equation for various ranges of data. For environmental biophysics applications the constants are $a=$ $0.611 \mathrm{kPa}, b=17.502$, and $c=240.97^{\circ} \mathrm{C}$ (Campbell and Norman 1998). The Tetens formula can also be used to predict the vapor pressure over ice. The coefficients for ice are $b=21.87$ and $c=265.5^{\circ} \mathrm{C}$.

From there, vapor pressure deficit (VPD) can is expressed as difference between saturation vapor pressure and actual mean vapor pressure: $\mathrm{VPD}=e_{s}-e_{a}$.

\section{Stomatal characteristics and leaf area}

Taking of stomata imprints was performed at the end of July 2010 and July 2011. Considering that stomata density is not constant over the whole leaf surface and that it increases from basal to distal region of the plant (Zacchini et al. 1997; Gitz and Baker 2009), imprints were made on the distal leaves, between $4^{\text {th }}$ and $5^{\text {th }}$ leaf veins, from 10 dominant saplings within each provenance. Samples were taken from the full sun leaves, fully expanded and hardened leaves from the spring flush, southwest-oriented and situated in the upper third part of the crown. Because of unequal degree of openness of stomata during the day, collecting of samples was made during clear, sunny weather, between 9 and 11 a.m.

Leaf prints of the stomata were made by print method or "kolodium method" (Wolf 1950), using nail polish to imprint the stomata from abaxial side of the leaves. The abaxial side of the leaf was cleaned first, using cotton ball, and the clear nail polish was painted across selected leaf area. After approximately 20 minutes, the dry film of polish was peeled off from the leaf by a piece of adhesive tape and mounted on a microscope slide.

Directly measured stomatal parameters were: the number of stomata per $\mathrm{mm}^{2}$ of leaf area (SD), length $\left(\mathrm{L}_{\mathrm{A}}\right)$ and width $\left(\mathrm{W}_{\mathrm{B}}\right)$ of stomata guard cell, stomatal aperture length $\left(\mathrm{L}_{\mathrm{a}}\right)$ and width $\left(\mathrm{W}_{\mathrm{b}}\right)$. Stomata measurements were carried out using light microscope "Olympus Vanox". The stomatal density per $\mathrm{mm}^{2}$ was counted on five randomly chosen fields of view using a software "tpsDIG2" (http://life.bio.sunysb. edu/ee/rohlf/software.html). Size of 10 stomata per five randomly chosen fields of view (totally 50 stomata per single leaf) was determined using software "QuickPhoto Camera 3.2.". The results obtained on field sub-samples were pooled and only one pooled value were used in the ANOVA.

From the directly measured parameters, the following parameters were calculated:

- stomatal pore surface of stomata guard cell: $\mathrm{SPS}_{\mathrm{LAWB}}=\left(\mathrm{L}_{\mathrm{A}} \times \mathrm{W}_{\mathrm{B}} \times \varpi\right) / 4\left[\mu \mathrm{m}^{2}\right]$ (Balasooriya et al. 2009),

- stomatal pore surface of a widely opened stomatal pore: $\operatorname{SPS}_{\mathrm{LaWb}}=\left(\mathrm{L}_{\mathrm{a}} \times \mathrm{W}_{\mathrm{b}} \times \varpi\right) / 4\left[\mu \mathrm{m}^{2}\right](\mathrm{Ba}-$ lasooriya et al. 2009),

- stomatal shape coefficient: $\mathrm{SSC}=100 \times \mathrm{W}_{\mathrm{b}} / \mathrm{L}_{\mathrm{a}}$ (Balasooriya et al. 2009),

- potential conductance index: $\mathrm{PCI}=\mathrm{L}_{\mathrm{A}}{ }^{2} \times \mathrm{SD} \times$ $10^{-4}$ (Holland and Richardson 2009),

- relative stomatal pore surface: $\mathrm{RSPS}=\left(\mathrm{SPS}_{\mathrm{LaWb}} \times\right.$ SD) $\times 100$ [\%] (Kardel et al. 2010).

On the same leaves which were previously used for stomata imprints, leaf area (LA) $\left[\mathrm{cm}^{2}\right]$ was measured using a AM 300 Field Portable Leaf Area Meter (ADC Bioscientific Ltd., Hoddesdon, UK).

\section{Statistical analysis of data}

All statistical analyses were carried out using the SAS version 9.1.3 (SAS Institute, Cary, NC 2011) and Statistica 10 (StatSoft, Inc.) software. In order to satisfy normal distribution, values of stomatal characteristics were subjected to log-transformation. Statistical importance of the different level sources of phenotypic variance was estimated by ANOVA procedure. Descriptive statistics (mean and standard deviation) and one-way analysis of variance, with 
Fisher LSD test (post hoc analysis), were provided for each parameter in order to verify the significance of differences among provenances within single years. Two-way ANOVA was performed in order to estimate differences among provenances in different years of investigation.

In order to standardize the phenotypic plasticity of different traits in certain provenances and thereby facilitating their comparison, the index of phenotypic plasticity $\left(\mathrm{PI}_{\mathrm{md}}\right)$, based on maximum and minimum medians, was calculated (Valladares et al. 2006): $\mathrm{PI}_{\mathrm{md}}=($ Maximum median-minimum median $) / \mathrm{max}-$ imum median.

Wilcoxon 2-sample test was used as a nonparametric procedure to compare the mean plasticity values of different provenances and stomatal traits (Pemac and Tucić 1998). Principal component analysis (PCA), based on matrix of correlations was applied in order to investigate possible patterns of variability between provenances. UPGMA (Unweighted Pair Group Method with Arithmetic Mean) cluster analysis was performed on standardized mean values of studied stomatal traits in order to classify the provenances into homogenous groups using the Euclidean distance.
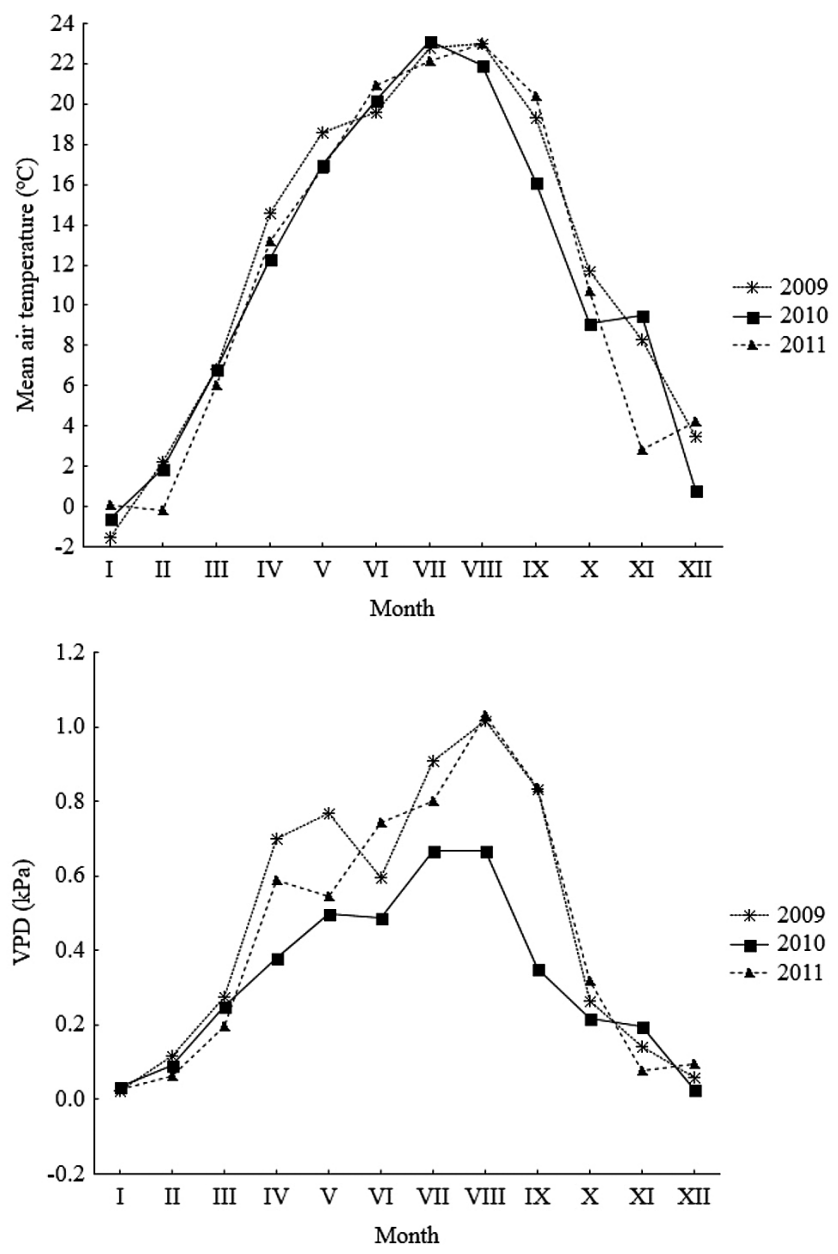

\section{Results and discussion}

The plasticity of stomatal density depends on more environmental factors, such as: air humidity (Torre et al. 2003), vapor pressure deficit (Leuschner 2002), temperature (Beerling and Chaloner 1993; Zhu et al. 2012), etc. For instance, Lichtenthaler et al. (1981) reported that sun leaves of beech possessed significantly higher stomatal density than shade leaves. Van Wittenberghe et al. (2012) found that stomatal density and stomatal pore surface increased along vertical canopy level of adult trees, resulting in significant increase of maximal stomatal conductance. Study performed by Gallé and Feller (2007) evidenced that drought stress induced closing of stomata and almost complete inhibition of net photosynthesis. However, the mechanisms responsible for stomatal initiation and development are not completely investigated (Beerling and Chaloner 1993; Miljkovic et al. 2013). For that reason, climate data in the present study are presented for the periods of bud set in the years before growth is measured (2009 and 2010), then recharge of soil moisture during the dormant period and, finally, during the growing seasons of interest (Fig. 1). Mean air temperature fluctuation was similar during the entire period of observation. Mean air

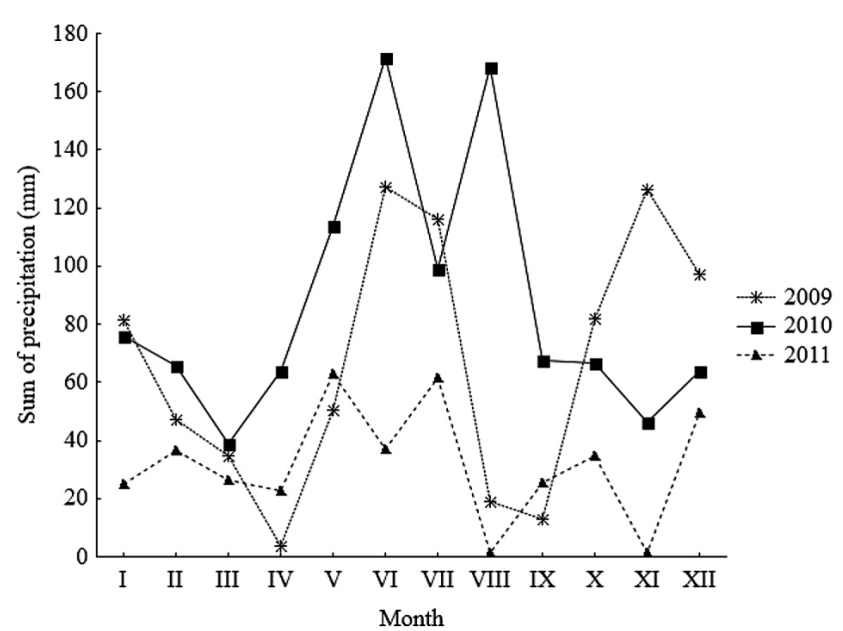

Fig. 1. A) mean air temperature $\left({ }^{\circ} \mathrm{C}\right)$, B) sum of precipitation (mm) and C) VPD (kPa) during 2009, 2010 and 2011. 


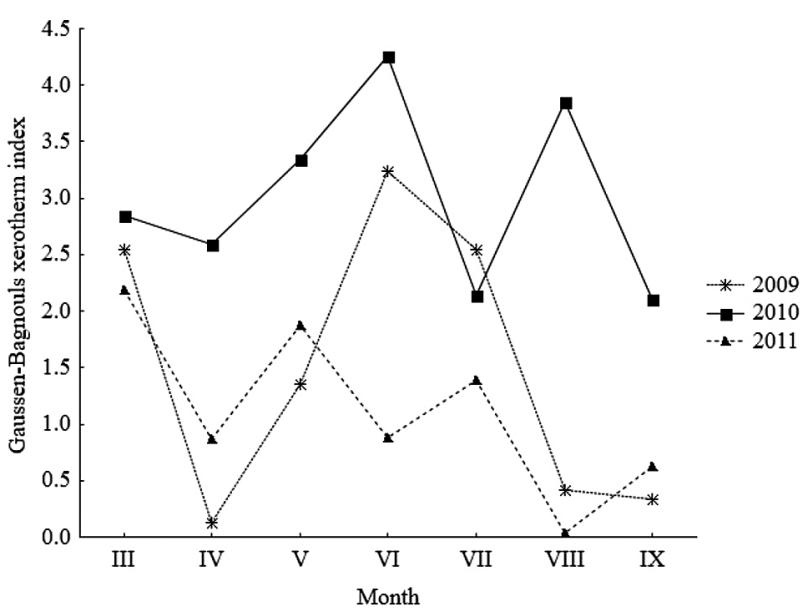

Fig 2. Values of Gaussen-Bagnouls xerotherm index during growing seasons of 2009, 2010 and 2011

temperature during spring and early summer (March - July) of 2010 and 2011 was similar in the both years $\left(15.8^{\circ} \mathrm{C}\right.$ and $15.9^{\circ} \mathrm{C}$, respectively) (Fig.1a). However, in the same time, precipitation sum in 2010 was twice as high as at the same period of $2011(487 \mathrm{~mm}$ and $210 \mathrm{~mm}$, respectively) (Fig. 1b). Similarly to precipitation, vapor pressure deficit in the given period was notably different and amounted to $0.46 \mathrm{kPa}$ and $0.57 \mathrm{kPa}$, respectively (Fig. 1c). Likewise, sums of precipitation during dormant periods differed significantely. Sum of precipitation between October 2009 and February 2010 amounted to $447 \mathrm{~mm}$, whereas precipitation sum in the same period of 2010-2011 amounted to $239 \mathrm{~mm}$. Mean air temperatures in this period reached $5^{\circ} \mathrm{C}$ and $3.9^{\circ} \mathrm{C}$, respectively. Moreover, low values of Gaussen-Bagnouls xerotherm index in 2011 indicated persisting drought for spring and early summer, the main period of stomata development (Fig. 2).

Stomata occur as a result of controlled series of successive symmetric and asymmetric divisions from precursor epidermal cells. The timing for the mechanisms of stomatal initiation lies in early ontogeny of leaf (Schoch et al. 1980). The mechanisms that determine stomatal patterning depend on both, environmental conditions (light, humidity, VPD, $\mathrm{CO}_{2}$ concentration, etc.) and internal anatomy (Casson and Gray 2008), which regulate their abundance on the leaf surface. Recent studies evidenced that signal about stomata formation in young leaves could also come from the environmental perception by old leaves (Lake et al. 2001). Nevertheless, it seems that different steps and genes in the stomatal pathway are under independent control of environmental treatments (Bergmann and Sack 2007). Similarly, many of plant hormones response to the environmental signals, regulating stomatal development (Saibo et al. 2003). For instance, abscisic acid (ABA) is the major precursor, which in terms of reduced water deficit in the soil and low air humidity leads to the reduction of

Table 2. Mean values \pm standard deviation from two-year period (2010-2011) for 10 traits in five European beech provenances. Means followed by the same letters within a variable are not significantly different $(\mathrm{p} \leq 0.05)$

\begin{tabular}{|c|c|c|c|c|c|}
\hline Parameter & BA32 & DE49 & AT56 & RO63 & SRB69 \\
\hline \multicolumn{6}{|c|}{2010} \\
\hline SD & $275 \pm 57.0^{\mathrm{a}}$ & $281 \pm 33.7^{a}$ & $256 \pm 26.6^{a}$ & $262 \pm 24.6^{a}$ & $210 \pm 29.0^{b}$ \\
\hline $\mathrm{L}_{\mathrm{A}}$ & $22.34 \pm 1.35^{\mathrm{a}}$ & $22.48 \pm 0.39^{a}$ & $22.23 \pm 0.57^{\mathrm{a}}$ & $22.42 \pm 0.59^{a}$ & $21.88 \pm 1.29^{a}$ \\
\hline $\mathrm{W}_{\mathrm{B}}$ & $18.10 \pm 1.06^{\mathrm{b}}$ & $18.69 \pm 0.51^{\mathrm{ab}}$ & $18.68 \pm 0.42^{\mathrm{ab}}$ & $18.98 \pm 0.46^{\mathrm{a}}$ & $18.81 \pm 1.53^{\mathrm{ab}}$ \\
\hline $\mathrm{L}_{\mathrm{a}}$ & $12.66 \pm 1.41^{\mathrm{a}}$ & $12.92 \pm 0.55^{\mathrm{a}}$ & $13.21 \pm 0.63^{\mathrm{a}}$ & $13.08 \pm 0.70^{\mathrm{a}}$ & $13.10 \pm 0.92^{\mathrm{a}}$ \\
\hline $\mathrm{W}_{\mathrm{b}}$ & $6.03 \pm 0.50^{a}$ & $6.17 \pm 0.37^{a}$ & $6.13 \pm 0.30^{a}$ & $6.10 \pm 0.31^{\mathrm{a}}$ & $6.38 \pm 0.92^{\mathrm{a}}$ \\
\hline SPS $_{\text {LAWB }}$ & $318.4 \pm 36.4^{\mathrm{a}}$ & $330.1 \pm 13.3^{\mathrm{a}}$ & $326.1 \pm 9.1^{\mathrm{a}}$ & $334.3 \pm 13.3^{\mathrm{a}}$ & $323.4 \pm 34.0^{\mathrm{a}}$ \\
\hline $\mathrm{SPS}_{\mathrm{LaWb}}$ & $60.3 \pm 11.1^{\mathrm{a}}$ & $62.7 \pm 5.3^{\mathrm{a}}$ & $63.6 \pm 4.0^{\mathrm{a}}$ & $62.7 \pm 4.8^{\mathrm{a}}$ & $66.0 \pm 13.0^{\mathrm{a}}$ \\
\hline SSC & $47.9 \pm 3.8^{\mathrm{a}}$ & $47.8 \pm 2.7^{\mathrm{a}}$ & $46.5 \pm 3.5^{\mathrm{a}}$ & $46.7 \pm 3.2^{\mathrm{a}}$ & $48.6 \pm 5.6^{a}$ \\
\hline PCI & $13.60 \pm 2.10^{a}$ & $14.20 \pm 1.77^{\mathrm{a}}$ & $12.68 \pm 1.61^{a}$ & $13.13 \pm 0.91^{\mathrm{a}}$ & $10.11 \pm 1.94^{b}$ \\
\hline RSPS & $1.628 \pm 0.28^{\mathrm{a}}$ & $1.772 \pm 0.32^{\mathrm{a}}$ & $1.63 \pm 0.22^{\mathrm{a}}$ & $1.631 \pm 0.05^{\mathrm{a}}$ & $1.379 \pm 0.29^{b}$ \\
\hline \multicolumn{6}{|c|}{2011} \\
\hline SD & $331 \pm 27.0^{\mathrm{a}}$ & $335 \pm 56.6^{a}$ & $317 \pm 28.0^{\mathrm{a}}$ & $325 \pm 22.0^{a}$ & $269 \pm 35.4^{\mathrm{b}}$ \\
\hline $\mathrm{L}_{\mathrm{A}}$ & $22.19 \pm 0.87^{\mathrm{a}}$ & $22.19 \pm 0.86^{\mathrm{a}}$ & $21.97 \pm 0.56^{\mathrm{a}}$ & $22.31 \pm 0.67^{\mathrm{a}}$ & $21.73 \pm 0.90^{\mathrm{a}}$ \\
\hline $\mathrm{W}_{\mathrm{B}}$ & $19.14 \pm 0.56^{a}$ & $19.19 \pm 0.55^{\mathrm{a}}$ & $19.02 \pm 0.27^{a}$ & $19.21 \pm 0.49^{a}$ & $17.78 \pm 0.88^{b}$ \\
\hline $\mathrm{L}_{\mathrm{a}}$ & $13.70 \pm 0.87^{\mathrm{a}}$ & $13.05 \pm 0.89^{a}$ & $13.02 \pm 0.56^{\mathrm{a}}$ & $13.16 \pm 0.90^{\mathrm{a}}$ & $13.38 \pm 0.79^{a}$ \\
\hline $\mathrm{W}_{\mathrm{b}}$ & $6.70 \pm 0.35^{\mathrm{a}}$ & $6.52 \pm 0.32^{\mathrm{a}}$ & $6.44 \pm 0.29^{a}$ & $6.11 \pm 0.30^{\mathrm{b}}$ & $6.10 \pm 0.33^{b}$ \\
\hline SPS $_{\text {LAWB }}$ & $333.7 \pm 18.4^{\mathrm{a}}$ & $334.7 \pm 21.5^{\mathrm{a}}$ & $328.2 \pm 9.36^{a}$ & $336.8 \pm 17.3^{a}$ & $303.9 \pm 27.3^{b}$ \\
\hline $\mathrm{SPS}_{\mathrm{LaWb}}$ & $72.3 \pm 8.1^{\mathrm{a}}$ & $67.0 \pm 7.3^{\mathrm{ab}}$ & $65.9 \pm 4.7^{\mathrm{b}}$ & $63.2 \pm 6.2^{\mathrm{b}}$ & $64.2 \pm 6.8^{\mathrm{b}}$ \\
\hline SSC & $49.0 \pm 1.4^{\mathrm{a}}$ & $50.1 \pm 2.4^{\mathrm{a}}$ & $49.5 \pm 2.4^{\mathrm{a}}$ & $46.6 \pm 3.0^{\mathrm{b}}$ & $45.6 \pm 2.0^{\mathrm{b}}$ \\
\hline PCI & $16.30 \pm 1.64^{a}$ & $16.42 \pm 1.64^{\mathrm{a}}$ & $15.31 \pm 2.42^{\mathrm{a}}$ & $16.15 \pm 1.18^{a}$ & $12.72 \pm 1.81^{b}$ \\
\hline RSPS & $2.387 \pm 0.30^{\mathrm{a}}$ & $2.222 \pm 0.31^{\mathrm{ab}}$ & $2.085 \pm 0.17^{\mathrm{b}}$ & $2.047 \pm 0.17^{\mathrm{b}}$ & $1.725 \pm 0.24^{\mathrm{c}}$ \\
\hline
\end{tabular}

Legend: SD - number of stomata per $\mathrm{mm}^{2}$ of leaf area; $\mathrm{L}_{\mathrm{A}}$ - length of stomata guard cell; $\mathrm{W}_{\mathrm{B}}-$ width of stomata guard cell; $\mathrm{L}_{\mathrm{a}}-$ stomatal aperture length; $\mathrm{W}_{\mathrm{b}}$ - stomatal aperture width; $\mathrm{SPS}_{\mathrm{LAWB}}-$ stomatal pore surface of stomata guard cell; $\mathrm{SPS}_{\mathrm{LaWb}}$ - stomatal pore surface of a widely opened stomatal pore; SSC - stomatal shape coefficient; PCI - potential conductance index; RSPS - relative stomatal pore surface. 
Srđan Stojnić et al.

Table 3. Results of Two-way ANOVA procedure performed separately for each of the stomatal traits

\begin{tabular}{lccccccccccc}
\hline \multicolumn{1}{c}{ Source of variation } & $\mathrm{df}$ & $\mathrm{SD}$ & $\mathrm{L}_{\mathrm{A}}$ & $\mathrm{W}_{\mathrm{B}}$ & $\mathrm{L}_{\mathrm{a}}$ & $\mathrm{W}_{\mathrm{b}}$ & SPS $_{\text {LAWB }}$ & SPS $_{\text {LaWb }}$ & SSC & PCI & RSPS \\
\hline Provenance (P) & 4 & $12.14^{* * *}$ & 1.46 & $3.62^{* * *}$ & 0.21 & 1.12 & $3.11^{* *}$ & 0.32 & 1.85 & $17.15^{* * *}$ & $10.61^{* * *}$ \\
Year (Y) & 1 & $65.12^{* * *}$ & 1.15 & 2.04 & 2.40 & $6.55^{* * *}$ & 0.06 & $5.59^{* *}$ & 1.29 & $54.19^{* * *}$ & $88.28^{* * *}$ \\
Interaction (P x Y) & 4 & 0.25 & 0.05 & $4.92^{* * *}$ & 1.56 & $3.12^{* *}$ & 1.70 & 2.31 & $2.60^{* *}$ & 0.35 & 1.21 \\
\hline
\end{tabular}

" $\mathrm{p}<0.05 ;{ }^{* *} \mathrm{p}<0.01 ;{ }^{* * *} \mathrm{p}<0.001$

Legend: SD - number of stomata per $\mathrm{mm}^{2}$ of leaf area; $\mathrm{L}_{\mathrm{A}}$ - length of stomata guard cell; $\mathrm{W}_{\mathrm{B}}$ - width of stomata guard cell; $\mathrm{L}_{\mathrm{a}}$ - stomatal aperture length; $\mathrm{W}_{\mathrm{b}}$ - stomatal aperture width; $\mathrm{SPS}_{\mathrm{LAWB}}$ - stomatal pore surface of stomata guard cell; $\mathrm{SPS}_{\mathrm{LaWb}}$ - stomatal pore surface of a widely opened stomatal pore; SSC - stomatal shape coefficient; PCI - potential conductance index; RSPS - relative stomatal pore surface.

the stomata frequency, turgor pressure, cell division rate, cell wall extension, etc. (Caspar et al. 2014).

According to the results obtained by our study, it seems that stomatal plasticity in investigated beech provenances was mainly linked to precipitation sums and VPD. It would be in agreement with the findings of Hamanishi et al. (2012) who reported that drought induced declines in stomatal conductance, as well as an alteration in stomatal development. Fraser et al. (2009) also found that reduction of water supply in the field caused an increase in stomatal density, while the range in temperatures of approximately $2.8^{\circ} \mathrm{C}$ did not have significant effect on stomatal density. Likewise, study of Lake and Woodward (2008) evidenced that number of stomata increased in response to increasing VPD. Similarly, studying an impact of high and low vapor pressure deficit on leaf anatomical traits, Carins Murphy et al. (2014) found that high VPD caused reduction of leaf area, whereas the leaf stomatal density increased. Our results are consistent with these findings, since we evidenced that leaf area in 2011 decreased, whereas stomatal density increased, comparing to 2010. According to Hovenden et al. (2012), differences in the leaves morphology between high and low humidity is the result of different number of cells, rather than their size (Hovenden et al. 2012). Nevertheless, future research is needed to get more precise answers about the impact of drought on the leaf anatomical structure of beech.

Results of ANOVA showed that during the 2010, statistically significant differences $(\mathrm{p} \leq 0.05)$ among provenances occurred only in the cases of $\mathrm{SD}, \mathrm{W}_{\mathrm{B}}$, PCI and RSPS (Table 3). Results obtained one year later, in 2011, revealed that except for these traits, provenances also differed significantly in $\mathrm{W}_{\mathrm{b}}$, $\mathrm{SPS}_{\mathrm{LAWB}}$, SPS $_{\mathrm{LaWb}}$ and SSC. Mean leaf area differed markedly $(\mathrm{p} \leq 0.05)$ between years and provenances observed, but significant correlation between leaf area and stomatal traits was not found (data not shown). Similar results were reported by Xu and Zhou (2008) for perennial grass, Leymus chinensis.

Impact of drought on stomatal size and density has been well-documented. The most often modification influenced by water stress causes an increase in stomatal density, which is accompanied with a decrease in stomatal length (Gindel 1969). Comparing the results of the ANOVA obtained in 2010 and 2011, significant differences among provenances were presented in the cases of SD, $\mathrm{W}_{\mathrm{b}}, \mathrm{SPS}_{\mathrm{LaWb}}, \mathrm{PCI}$ and RSPS (Table 3). Although Holland and Richardson (2009) reported that stomatal density and guard cell length are both sensitive to environmental conditions and that considerable genotypic variation and phenotypic plasticity occurred in these traits, our study showed that differences among provenances in regards to guard cell length were not statistically significant, despite the decrease of $L_{A}$ in dry year for all provenances (Table 2). This is in agreement with the results presented by other authors, who found that stomatal density appears to be relatively plastic compared to stomatal length (Richardson et al. 2001) and therefore, potentially adaptive to environmental change (Lake and Woodward 2008). Our study also showed that stomatal density increased with drought, which is consistent with the results obtained in some other plant species (Klooster and Palmer-Young 2004; Fraser et al. 2009). Although some authors found significant influence of drought on stomatal size (Xu and Zhou 2008), presence of non-significant differences among provenances, in our case, suggests that effect of abiotic factors on stomatal size may depend on the plant species.

Average reaction norms were steep for each of the measured traits, indicating the possibility of plastic response of provenance to changes in water regime, conditioned by the difference in the weather between the two years (Fig. 3). In the cases of SD and PCI, lines were parallel, only suggesting an effect of environment (Fig. 3). Relatively parallel reaction norms for these traits indicate a low level of genetic variability in their plasticity. In contrast, the reaction norms for certain traits had a complex shape. In these cases, rank of individual provenances varied depending on weather conditions during the year, leading to the intersection with the norms of reaction of other provenances. Crossing reaction norms of different provenances, observed for $\mathrm{W}_{\mathrm{b}}$, $\mathrm{SPS}_{\mathrm{LaWb}}$ and RSPS, reveal the existence of genetic variability in plasticity for these traits. However, in the cases of SPS ${ }_{\text {Lawb }}$ and RSPS, the results of two-factorial analysis of variance did not confirm statistically significant interaction between provenance and year (Table 3). The lack of a statistically significant interaction between prove- 

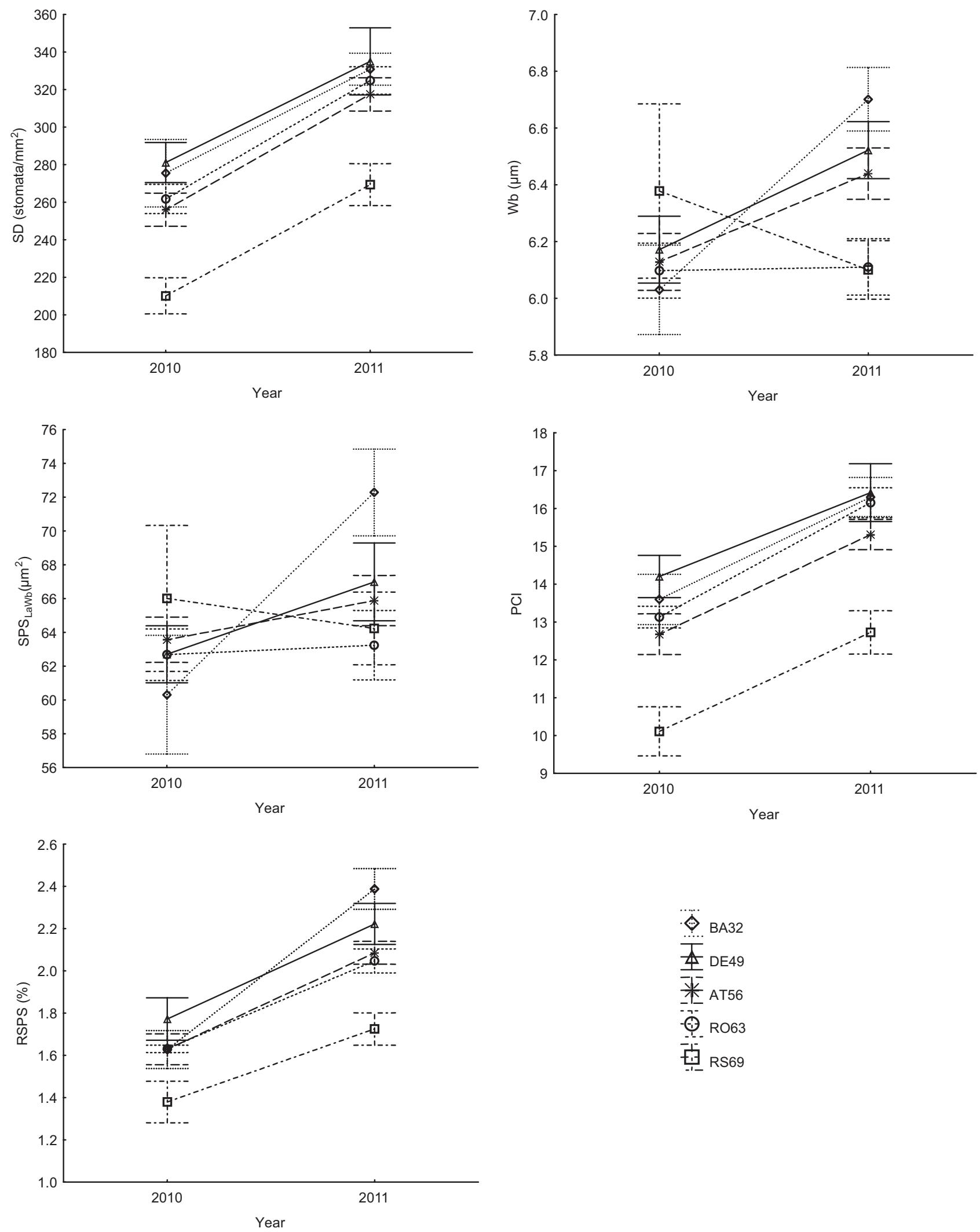

Fig 3. Reaction norm plots (mean \pm standard error) for five stomatal traits (SD, $\mathrm{W}_{\mathrm{b}}, \mathrm{SPS}_{\mathrm{LaWb}}$, PCI and RSPS) in investigated European beech provenances, observed in 2010 and 2011. In the figure are presented only the traits which differ significantly between years 
Table 4. Median phenotypic plasticity $\left(\mathrm{PI}_{\mathrm{md}}\right.$ ) and interquartile range (IQR) for 10 stomatal traits across five European beech provenances, observed during 2010 and 2011

\begin{tabular}{|c|c|c|c|c|c|c|c|c|c|c|}
\hline \multirow{2}{*}{ Trait } & \multicolumn{2}{|c|}{ BA32 } & \multicolumn{2}{|c|}{ DE49 } & \multicolumn{2}{|c|}{ AT56 } & \multicolumn{2}{|c|}{ RO63 } & \multicolumn{2}{|c|}{ RS69 } \\
\hline & $\mathrm{PI}_{\mathrm{md}}$ & IQR & $P I_{m d}$ & IQR & $\mathrm{PI}_{\mathrm{md}}$ & IQR & $\mathrm{PI}_{\mathrm{md}}$ & IQR & $\mathrm{PI}_{\mathrm{md}}$ & IQR \\
\hline SD & 0.20 & 58.3 & 0.16 & 71.5 & 0.23 & 41.2 & 0.21 & 27.3 & 0.17 & 49.0 \\
\hline $\mathrm{L}_{\mathrm{A}}$ & 0.00 & 1.83 & 0.01 & 0.61 & 0.02 & 0.79 & 0.01 & 0.96 & 0.01 & 1.60 \\
\hline $\mathrm{W}_{\mathrm{B}}$ & 0.06 & 0.86 & 0.03 & 0.67 & 0.01 & 0.55 & 0.01 & 0.51 & 0.04 & 1.45 \\
\hline $\mathrm{L}_{\mathrm{a}}$ & 0.10 & 1.85 & 0.01 & 0.94 & 0.01 & 0.94 & 0.01 & 1.22 & 0.04 & 0.60 \\
\hline $\mathrm{W}_{\mathrm{b}}$ & 0.12 & 0.65 & 0.07 & 0.34 & 0.04 & 0.37 & 0.02 & 0.29 & 0.04 & 0.95 \\
\hline $\mathrm{SPS}_{\text {LAWB }}$ & 0.07 & 46.6 & 0.01 & 16.5 & 0.01 & 10.5 & 0.00 & 19.9 & 0.04 & 33.9 \\
\hline $\mathrm{SPS}_{\text {LaWb }}$ & 0.21 & 13.4 & 0.07 & 5.41 & 0.04 & 4.43 & 0.03 & 6.42 & 0.08 & 14.3 \\
\hline SSC & 0.02 & 3.86 & 0.04 & 3.27 & 0.08 & 3.68 & 0.00 & 4.00 & 0.01 & 4.34 \\
\hline PCI & 0.21 & 2.12 & 0.14 & 4.10 & 0.18 & 2.06 & 0.16 & 1.19 & 0.17 & 2.10 \\
\hline RSPS & 0.34 & 0.43 & 0.18 & 0.45 & 0.24 & 0.21 & 0.23 & 0.16 & 0.20 & 0.26 \\
\hline
\end{tabular}

nance and year indicates a low level of genetic variability in the plasticity of these traits. Provenances displayed relatively convergent norms of reaction in terms of SD, PCI and RSPS (Fig. 3). Pemac and Tucić (1998) considered that convergent norms of reaction are particularly common in traits that directly contribute to functional adjustment to limiting environmental conditions.

Plasticity index represents the percentage difference in phenotypic value of the certain trait manifested in different years, under contrasting climate conditions. Higher values of median phenotypic plasticity in terms of SD, PCI and RSPS, which was recorded in all provenances, imply the ecological importance of these characteristics, because it increases the ability to control the rate of gas exchange between the leaf and external environment, and thereby adjusting plants to stress conditions caused by drought (Table 4). However, the low values of PI ${ }_{m d}$ observed for $\mathrm{L}_{\mathrm{A}}, \mathrm{W}_{\mathrm{B}}, \mathrm{L}_{\mathrm{a}}$, SPS ${ }_{\mathrm{LAWB}}$ and SSC verified the limited plasticity of these traits to adapt to changes in environmental conditions. According to the results of Wilcoxon 2-sample test, statistically

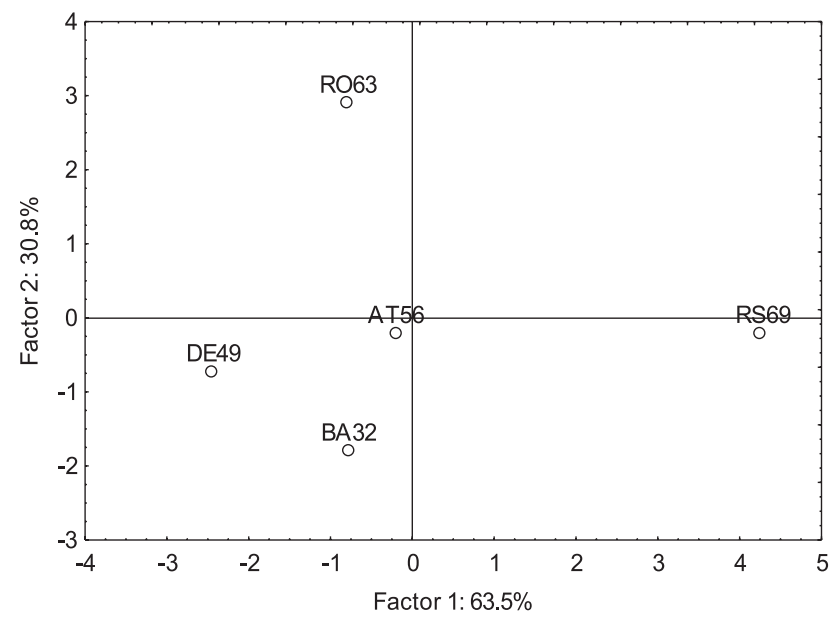

Fig 4. Principal component ordination of five European beech provenances according to their mean values of investigated leaf stomatal features significant differences in mean plasticity indices of SD, PCI and RSPS $(p<0.0001)$ were observed, suggesting that these traits, regardless of provenance, had a different response to the climatic conditions in two successive seasons. However, results of Wilcoxon 2-sample test showed that provenances did not differ significantly in the values of plasticity indices ( $\mathrm{p}>0.3205)$.

Results of principal component analysis (PCA) evidenced that first three principal components explained over $99 \%$ of variability (Table 5). PC1 explained $63 \%$ of total variation. The highest contribution on PCl corresponded to stomatal density $(-0.982)$ and potential conductance index $(-0.987)$. PC2 explained another $31 \%$ of variation. Provenance RS69 was separated from the rest, since it was characterized by the lowest values of SD and PCI (Fig. 4). PC2 correlated negatively with stomatal aperture width $(-0.955)$ and with the stomatal pore surface of a widely opened stomatal pore $(-0.971)$. PC3 explained approximately $5 \%$ of total variance and was in negative correlation only with stomatal aperture length $(-0.520)$.

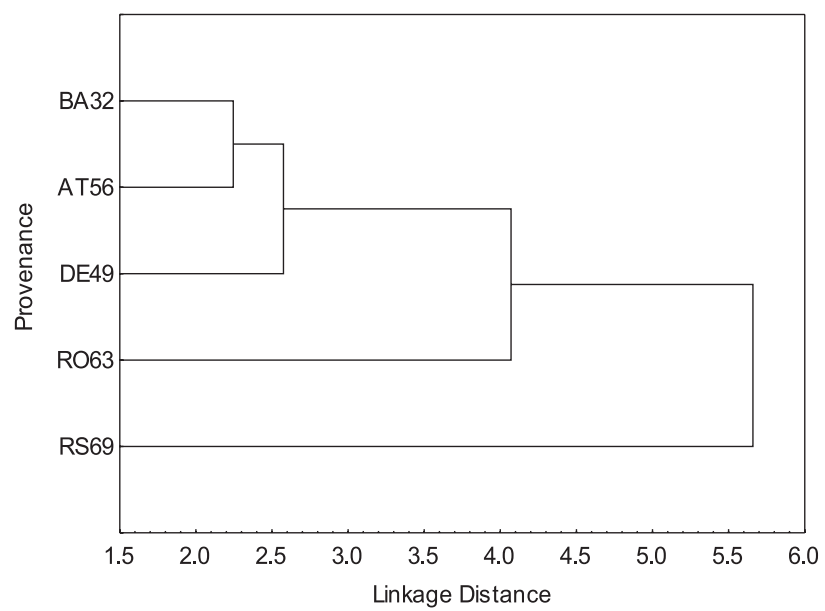

Fig 5. Dendrogram for the studied European beech provenances based on Euclidean distances using UPGMA method 
Table 5. Eigenvalues, proportion of total variability and correlation between the investigated variables and the first three principal components (PCs)

\begin{tabular}{lccc}
\hline \multicolumn{1}{c}{ Trait } & PC 1 & PC 2 & PC3 \\
\hline $\mathrm{SD}$ & -0.982 & -0.118 & -0.145 \\
$\mathrm{~L}_{\mathrm{A}}$ & -0.933 & 0.229 & -0.233 \\
$\mathrm{~W}_{\mathrm{B}}$ & -0.838 & 0.517 & 0.095 \\
$\mathrm{~L}_{\mathrm{a}}$ & 0.849 & -0.042 & -0.520 \\
$\mathrm{~W}_{\mathrm{b}}$ & -0.278 & -0.955 & 0.097 \\
SPS $_{\text {LAWB }}$ & -0.906 & 0.420 & -0.042 \\
SPS $_{\text {LaWb }}$ & 0.115 & -0.971 & -0.208 \\
$\mathrm{SSC}$ & -0.578 & -0.779 & 0.243 \\
PCI & -0.987 & -0.049 & -0.153 \\
RSPS & -0.932 & -0.315 & -0.176 \\
Eigenvalue & 6.35 & 3.08 & 0.52 \\
\% Var. & 63.45 & 30.77 & 5.23 \\
Cum. \% & 63.45 & 94.22 & 99.45 \\
\hline
\end{tabular}

Legend: SD - number of stomata per $\mathrm{mm}^{2}$ of leaf area; $\mathrm{L}_{\mathrm{A}}$ - length of stomata guard cell; $W_{B}$ - width of stomata guard cell; $L_{a}$ - stomatal aperture length; $\mathrm{W}_{\mathrm{b}}$ - stomatal aperture width; $\mathrm{SPS}_{\mathrm{LAWB}}-$ stomatal pore surface of stomata guard cell; SPS Lawb $_{-}$stomatal pore surface of a widely opened stomatal pore; SSC - stomatal shape coefficient; PCI - potential conductance index; RSPS - relative stomatal pore surface.

Cluster analysis was performed on the basis of standardized mean values of studied stomatal traits obtained in two successive growing seasons. Three clusters (groups) were distinguished (Fig. 5). Three provenances originating from Austria, Bosnia and Germany represented the first group, whereas the second and third group consisted of only one provenance (RO63 and RS69, respectively). Formation of groups divergent from those represented by geographic origin showed existence of substantial genetic variability among European beech provenances both from different and similar geographic origins (Pluta et al. 2012). Similar results were reported by Pluta et al. (2012) for blackcurrant and by Mohamed et al. (2011) for palm, even though their results were based on the cultivar level.

\section{Conclusion}

Results of the study showed that stomatal density and all parameters calculated from SD were plastic in their response to climate during observed years. In contrast, differences among provenances in regard to guard cell length were not statistically significant, even though guard cell length decreased in the dry year in all provenances. The highest values of median phenotypic plasticity were observed for stomatal density, potential conductance index and relative stomatal pore surface. Norm of reactions were steep in all parameters, suggesting a possibility of plastic response of all provenances toward changes in soil water regime influenced by climate conditions dur- ing the year. Based on the obtained results, it is possible that European beech may be capable to adapt to a changing climate through changes in stomatal density, rather than stomatal size.

\section{Acknowledgement}

This paper was realized as a part of the project "Biosensing Technologies and Global System for Long-Term Research and Integrated Management of Ecosystems" (III 43002) financed by the Ministry of Education and Science of the Republic of Serbia within the framework of integrated and interdisciplinary research for the period 2011-2014.

\section{References}

Bagnouls F., Gaussen H. 1953. Saison sčche et indice xérothermique. Documents pour les Cartes des Productions Vegetales, Tome III. Toulouse.

Balasooriya B.L.W.K., Samson R., Mbikwa F., Vitharana U.W.A., Boeckx P., van Meirvenne M. 2009. Biomonitoring of urban habitat quality by anatomical and chemical leaf characteristics. Environmental and Experimental Botany 65: 386-394.

Beerling D.J., Chaloner W.G. 1993. Stomatal density responses of Egyptian Olea europaea L. leaves to $\mathrm{CO}_{2}$ change since $1327 \mathrm{BC}$. Annals of Botany 71: 431-435.

Bergmann D.C., Sack F.D. 2007. Stomatal development. Annual Review of Plant Biology 58: 163181.

Buck A.L. 1981. New equations for computing vapor pressure and enhancement factor. Journal of Applied Meteorology 20: 1527-1532.

Campbell G.S., Norman J.M. 1998. An Introduction to Environmental Biophysics. Springer Science \& Business Media.

Carins Murphy M.R., Jordan G.J., Brodribb T.J. 2014. Acclimation to humidity modifies the link between leaf size and the density of veins and stomata. Plant, Cell and Environment 37: 124-131.

Caspar C.C.C., Oliver J., Casson S., Gray J.E. 2014. Putting the brakes on: abscisic acid as a central environmental regulator of stomatal development. New Phytologist 202: 376-391.

Casson S., Gray J.E. 2008. Influence of environmental factors on stomatal development. New Phytologist 178: 9-23.

Flexas J., Medrano H. 2002. Drought-inhibition of photosynthesis in $\mathrm{C}_{3}$ plants: stomatal and non-stomatal limitations revisited. Annals of Botany 89 : $183-189$.

Fraser H.L., Greenall A., Carlyle C., Turkington R., Ross Friedman C. 2009. Adaptive phenotypic plasticity of Pseudoroegneria spicata: response of 
stomatal density, leaf area and biomass to changes in water supply and increased temperature. Annals of Botany 103: 769-775.

Gallé A., Feller U. 2007. Changes of photosynthetic traits in beech saplings (Fagus sylvatica) under severe drought stress and during recovery. Physiologia Plantarum 131: 412-421.

Gitz D.C., Baker J.T. 2009. Methods for creating stomatal impressions directly onto archivable slides. Agronomy Journal 101: 232-236.

Gindel I. 1969. Stomatal Number and Size as Related to Soil Moisture in Tree Xerophytes in Israel. Ecology 50: 263-267.

Grassi G., Magnani F. 2005. Stomatal, mesophyll conductance and biochemical limitations to photosynthesis as affected by drought and leaf ontogeny in ash and oak trees. Plant, Cell and Environment 28: 834-849.

Hamanishi E.T., Thomas B.R., Campbell M.M. 2012. Drought induces alterations in the stomatal development program in Populus. Journal of Experimental Botany 63: 4995-4971.

Holland N., Richardson A.D. 2009. Stomatal Length Correlates with Elevation of Growth in Four Temperate Species. Journal of Sustainable Forestry 28: 63-73.

Hovenden M.J., Vander Schoor J.K., Osanai Y. 2012. Relative humidity has dramatic impacts on leaf morphology but little effect on stomatal index or density in Nothofagus cunninghamii (Nothofagaceae). Australian Journal of Botany 60: 700-706.

Jones H.G. 1987. Breeding for stomatal characters. In: Stomatal function. Zeiger E., Farquar G.D. Cowan I.R. (eds.). Stanford University Press, Stanford, California. pp. 431-444.

Kardel F., Wuyts K., Babanezhad M., Vitharana U.W.A., Wuytack T., Potters G., Samson R. 2010. Assessing urban habitat quality based on specific leaf area and stomatal characteristics of Plantago lanceolata L. Environmental Pollution 158: 788794.

Klooster B., Palmer-Young E. 2004. Water stress marginally increases stomatal density in E. canadensis, but not in A. gerardii. Tillers 5: 35-40.

Lake J.A., Quick W.P., Beerling D.J., Woodward F.I. 2001. Plant development. Signals from mature to new leaves. Nature 411: 154.

Lake J.A., Woodward F.I. 2008. Response of stomatal numbers to $\mathrm{CO}_{2}$ and humidity: control by transpiration rate and abscisic acid. New Phytologist 179: 397-404.

Lichtenthaler H.K., Buschmann C., Döll M., Fietz H.J., Bach T., Kozel U., Meier D., Rahmsdorf U. 1981. Photosynthetic activity, chloroplast ultrastructure, and leaf characteristics of highlight and low-light plants and of sun and shade leaves. Photosynthesis Research 2: 115-141.
Leuschner C. 2002. Air humidity as an ecological factor for woodland herbs: leaf water status, nutrient uptake, leaf anatomy, and productivity of eight species grown at low or high VPD levels. Flora 197: 262-274.

Lindner M., Maroschek M., Netherer S., Kremer A., Barbati A., Garcia-Gonzalo J., Seidl R., Delzon S., Corona P., Kolstrom M., Lexer M., Marchetti M. 2010. Climate change impacts, adaptive capacity, and vulnerability of European forest ecosystems. Forest Ecology and Management 259: 698-709.

Löf M., Bolte A., Welander N.T. 2005. Interacting effects of irradiance and water stress on dry weight and biomass partitioning in Fagus sylvatica seedlings. Scandinavian Journal of Forest Research 20: 322-328.

Meier I.C., Leuschner C. 2008. Genotypic variation and phenotypic plasticity in the drought response of fine roots of European beech. Tree Physiology 28: 297-309.

Mészáros I., Veres S., Kanalas P., Oláh V., Szőllősi E., Sárvári E., Lévai L., Lakatos G. 2007. Leaf Growth and Photosynthetic Performance of Two Co-existing Oak Species in Contrasting Growing Seasons. Acta Silvatica \& Lignaria Hungarica 3: 7-20.

Miljkovic D., Avramov S., Vujic V., Rubinjoni L., Klisaric Barisic N., Zivkovic U., Tarasjev A. 2013. Between-clone, between-leaf and within-leaf variation in leaf epidermis traits in Iris pumila clones. Genetika 45: 297-308.

Mohamed V.O.M.A., Zein E.O.B., Fouteye M.M.L., Taleb K.O.D., Trifi M., Ali O.M.S. 2011. Use of multivariate analysis to assess phenotypic diversity of date palm (Phoenix dactylifera L.) cultivars. Scientia Horticulturae 127: 367-371.

Pemac D., Tucić B. 1998. Reaction norms of juvenile traits to light intensity in Iris pumila (Iridaceae): A comparison of populations from exposed and shaded habitats. Plant Systematics and Evolution 209: 159-176.

Pluta S., Madry W., Sieczko L. 2012. Phenotypic diversity for agronomic traits in a collection of blackcurrant (Ribes nigrum L.) cultivars evaluated in Poland. Scientia Horticulturae 145: 136-144.

Republički hidrometeorološki zavod Republike Srbije. 2010. Meteorološki godišnjak 1. Klimatološki podaci 2009. Republika Srbija. http://www.hidmet.gov.rs/

Republički hidrometeorološki zavod Republike Srbije. 2011. Meteorološki godišnjak 1. Klimatološki podaci 2010. Republika Srbija. http://www.hidmet.gov.rs/

Republički hidrometeorološki zavod Republike Srbije. 2012. Meteorološki godišnjak 1. Klimatološki podaci 2011. Republika Srbija. http://www.hidmet.gov.rs/ 
Richardson A.D., Ashton P.M.S., Berlyn G.P., McGroddy M.E., Cameron I.R. 2001. Within-crown foliar plasticity of western hemlock, Tsuga heterophylla, in relation to stand age. Annals of Botany 88: 1007-1015.

Royer D.L. 2001. Stomatal density and stomatal index as indicators of paleoatmospheric $\mathrm{CO}_{2}$ concentration. Review of Palaeobotany and Palynology 114: 1-28.

Saibo N.J.M, Vriezen W.H., Beemster G.T., Van der Straeten D. 2003. Growth and stomata development of Arabidopsis hypocotyls are controlled by gibberellins and modulated by ethylene and auxins. The Plant Journal 33: 989-1000.

SAS Institute, INC. 2011. SAS/STAT Users Guide, Version 9.1.3. Cary, NC: SAS Institute, Inc.

Schoch P.G., Zinsou C., Sibi M. 1980. Dependence of the stomatal index on environmental factors during stomatal differentiation in leaves of Vigna sinensis L. I. Effect of light intensity. Journal of Experimental Botany 31: 1211-1216.

Statsoft, INC. 2011. STATISTICA (data analysis software system), version 10. www.statsoft.com.

Stojnić S., Orlović S., Galić Z., Vasić V., Vilotić D., Knežević M., Šijačić-Nikolić M. 2012. Stanišne i klimatske karakteristike u provenijeničnim testovima bukve na Fruškoj gori i u Debelom lugu. Topola 189/190: 145-162.

Stojnić S., Sass-Klaassen U., Orlović S., Matovic B., Eilmann B. 2013. Plastic growth response of European beech provenances to dry site conditions. IAWA Journal 34: 475-484.

Sultan S.E. 2000. Phenotypic plasticity for plant development, function and life history. Trends in Plant Science 5: 537-542.
Torre S., Fjeld T., Gislerød H.R., Moe R. 2003. Leaf anatomy and stomatal morphology of greenhouse roses grown at moderate or high air humidity. Journal of the American Society for Horticultural Science 128: 598-602.

Valladares F., Sanchez-Gomez D., Zavala M.A. 2006. Quantitative estimation of phenotypic plasticity: bridging the gap between the evolutionary concept and its ecological applications. Journal of Ecology 94: 1103-1116.

Van Wittenberghe S., Adriaenssens S., Staelens J., Verheyen K., Samson R. 2012. Variability of stomatal conductance, leaf anatomy, and seasonal leaf wettability of young and adult European beech leaves along a vertical canopy gradient. Trees 26: 1427-1438.

Wolf L. 1950. Mikroskopicka tehnica, Statni zdravotnicke nakladatelstva. Praha.

Xu Z., Zhou G. 2008. Responses of leaf stomatal density to water status and its relationship with photosynthesis in a grass. Journal of Experimental Botany 59: 3317-3325.

Zacchini M., Morini S., Vitagliano C. 1997. Effect of photoperiod on some stomatal characteristics of in vitro cultured fruit tree shoots. Plant, Cell, Tissue Organ Culture 49: 195-200.

Zhu Y.H., Kang H.Z., Xie Q., Wang Z., Yin S., Liu C.J. 2012. Pattern of leaf vein density and climate relationship of Quercus variabilis populations remains unchanged with environmental changes. Trees: Structure and Function 26: 597-607. 